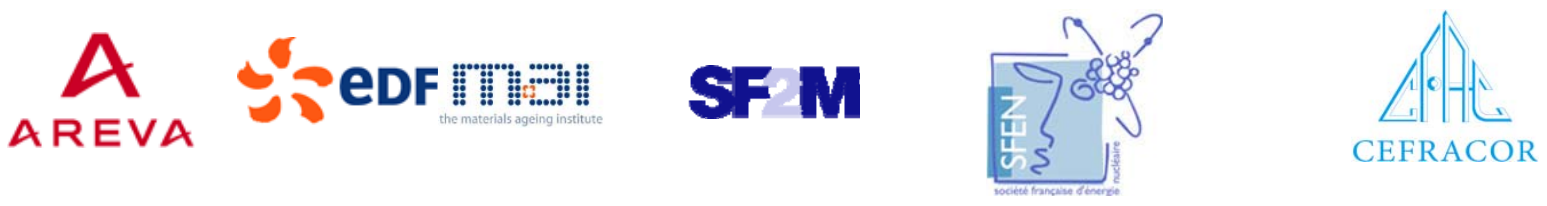

\section{MIN口S}

Centre of Excellence for Nuclear Materials

\section{Workshop}

Materials Innovation for Nuclear Optimized Systems
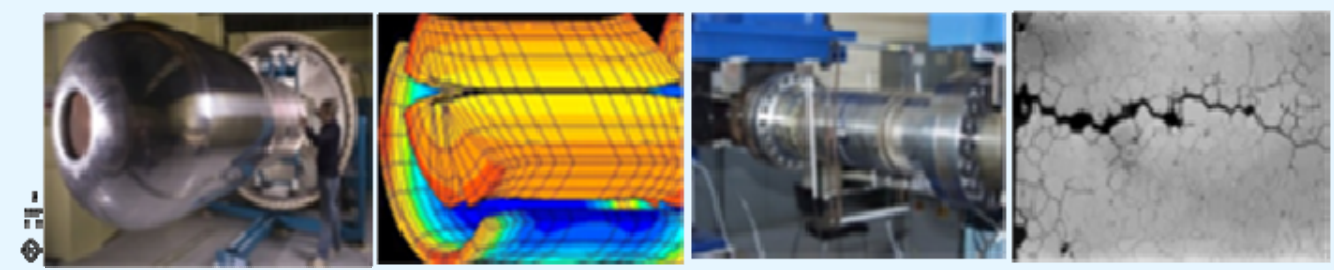

December 5-7, 2012, CEA - INSTN Saclay, France

\section{Fabien ONIMUS et al.}

\author{
CEA (France)
}

Impact of Fuel Assembly Transportation on Zirconium Alloys: toward a Mechanistic Understanding

Workshop organized by:

Christophe GALLÉ, CEA/MINOS, Saclay - christophe.galle@cea.fr Constantin MEIS, CEA/INSTN, Saclay - constantin.meis@cea.fr 
MINDS

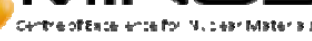

\title{
Impact of Fuel Assembly Transportation on Zirconium Alloys: toward a Mechanistic Understanding
}

\author{
Fabien ONIMUS ${ }^{1}$, Joël RIBIS ${ }^{1}$, Brice BOURDILIAU ${ }^{2}$, Chantal CAPPELAERE ${ }^{2}$ \\ ${ }^{1}$ CEA-DEN-DMN, Service de Recherches Métallurgiques Appliquées, SRMA (Saclay, France) \\ ${ }^{2}$ CEA-DEN-DMN, Service d'Etudes des Matériaux Irradiés, SEMI (Saclay, France)
}

Zirconium alloys are commonly used in pressurized water reactor as fuel rod cladding tubes. After irradiation and cooling in pool, the spent nuclear fuel assemblies are transported for wet storage to a devoted site. During dry transportation, at temperatures around $400^{\circ} \mathrm{C}$, the cladding experiences a creep deformation under the hoop stress induced by the internal pressure of the fuel rod. A recovery of the radiation damage can occur during transportation that can affect the subsequent mechanical properties [1].

The recovery of the radiation damage during heat treatments has been investigated using microhardness tests at room temperature on neutron irradiated cladding materials made of fully recrystallized $\mathrm{Zr}-1 \% \mathrm{Nb}$ alloy. Transmission electron microscopy (TEM) observations performed on irradiated thin foils have also shown that, simultaneously with the recovery of the hardness, the dislocation loop density, induced by irradiation, falls while the loop size increases (Fig. 1). Moreover, the TEM analysis has revealed that only vacancy loops are present in the material after long-term annealing, the interstitial loops having entirely disappeared. A numerical cluster dynamic modeling [2] has been used in order to reproduce the material recovery for various annealing conditions (Fig. 1).

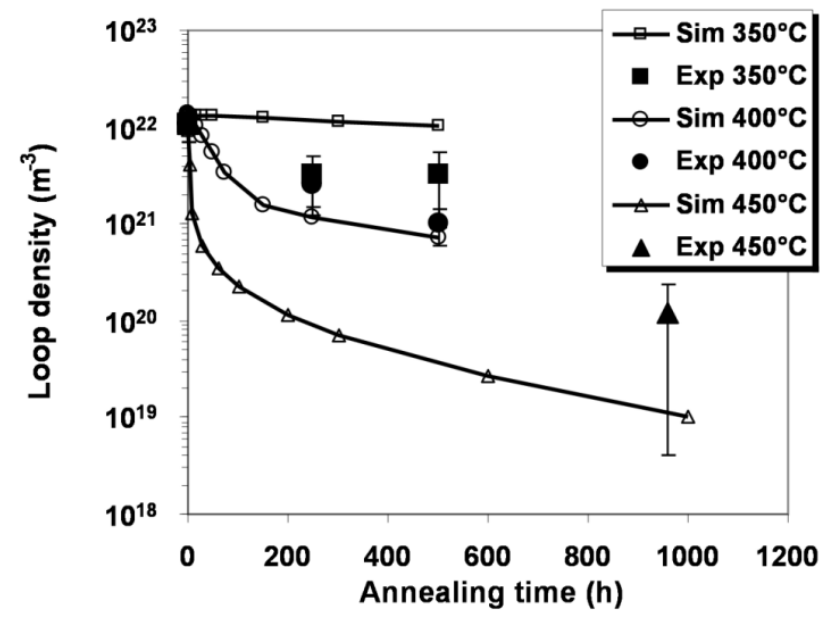

(a)

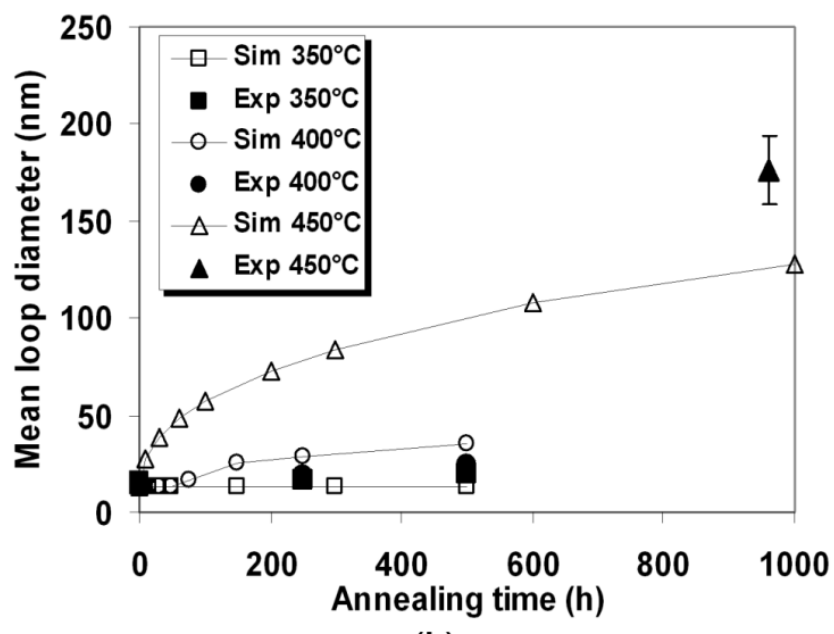

(b)

Figure 1: Evolution of : (a) the loop density and (b) the loop diameter during a thermal annealing at $350^{\circ} \mathrm{C}, 400^{\circ} \mathrm{C}$ and $450^{\circ} \mathrm{C}$. Experiment (Exp) and modeling (Sim).

Furthermore, the mechanical behavior of the cladding after post-irradiation creep test has been investigated. Creep tests under internal pressure were conducted at 400 and $420^{\circ} \mathrm{C}$ on the neutron irradiated recrystallized $\mathrm{Zr}-1 \% \mathrm{Nb}$ alloy. After depressurization and cooling, ring tensile tests were carried out at room temperature. In addition, transmission electron microscopy observations have been performed after testing [3]. The post-creep mechanical response exhibited a decrease of the strength compared to the as-irradiated material. This decrease is associated with a significant recovery of the ductility, which becomes close to the ductility of the unirradiated material (Fig. 2). 
The transmission electron microscopy examinations, conducted on ring samples, revealed that the radiation defects have been annealed (Fig. 3). It was also observed that as for the unirradiated material, the deformation occurred homogeneously throughout the grains. No dislocation channeling was observed contrary to the as-irradiated material [4]. These observations explain the recovery of the strength and of the ductility after post-irradiation creep that may also occur during dry transportation.

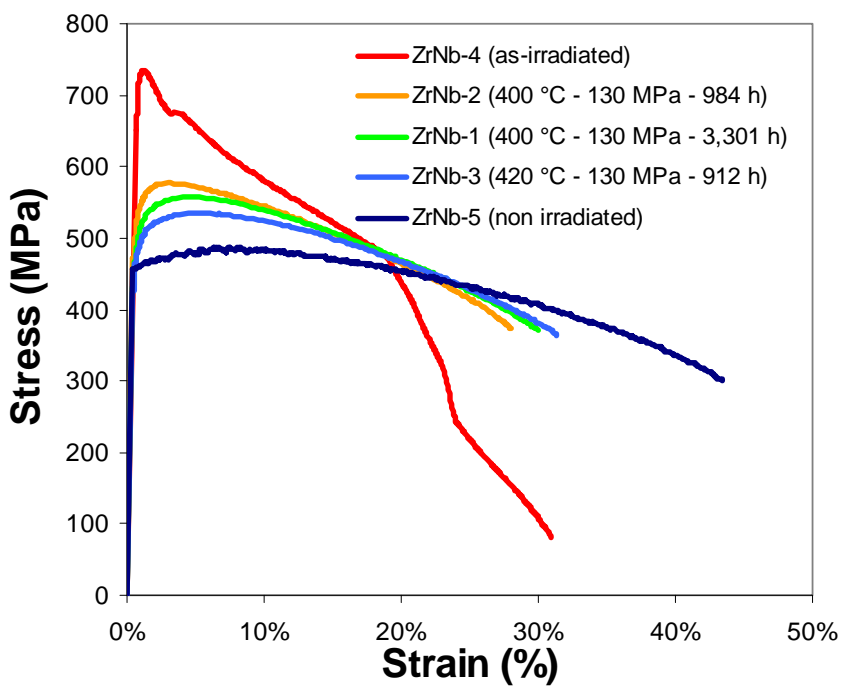

Figure 2: Stress-strain curve obtained during ring tensile test on $\mathrm{Zr}-1 \% \mathrm{Nb}$ alloy at room temperature.

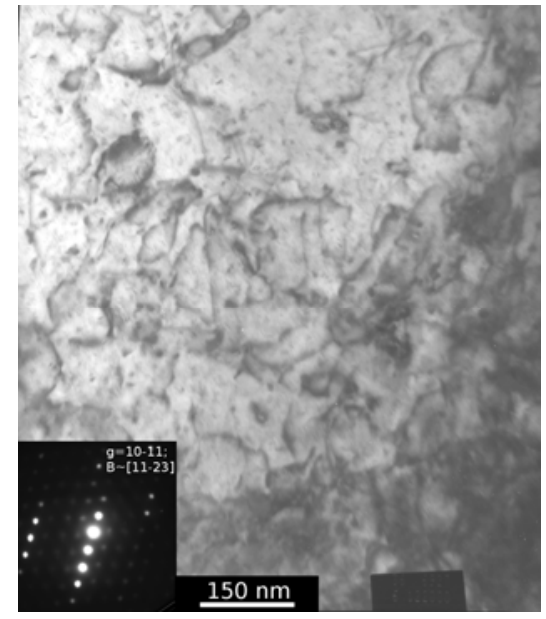

Figure 3: Dislocation microstructure after ring tensile test subsequent to a postirradiation creep test at $420^{\circ} \mathrm{C}$.

\section{References}

[1] C. Ferry, C. Poinssot, C. Cappelaere, L. Desgranges, C. Jegou, F. Miserque, J.P. Piron, D. Roudil, J.M. Gras. Journal of Nuclear Materials, 2006, Volume: 352, Pages: 246-253.

[2] J. Ribis, F. Onimus, J.-L. Béchade, S. Doriot, A. Barbu, C. Cappelaere, C. Lemaignan. Journal of Nuclear Materials, 2010, Volume: 403, Pages: 135-146.

[3] B. Bourdiliau, F. Onimus, C. Cappelaere, V. Pivetaud, P. Bouffioux, V. Chabretou, A. Miquet. Journal of ASTM International, 2011, Vol. 7, No. $9\left(16^{\text {th }}\right.$ International Symposium on Zirconium in the Nuclear Industry, ASTM STP 1529, M. Limbäck, P. Barberis Eds, West Conshohocken, PA, 2011, pp. 929-953).

[4] F. Onimus, I. Monnet, J.-L. Bechade, et al. Journal of Nuclear Materials, 2004, Volume: 328, Issue: 2-3, Pages: 165-179. 

zirconium alloys: toward a mechanistic understanding

F. Onimus, J. Ribis, B. Bourdiliau, C. Cappelaere 


\section{cea}

INDUSTRIAL BACKGROUND : END OF LIFE OF THE FUEL ASSEMBLY

$\because$ MIN口S

MINOS Spent Nuclear Fuel Assembly
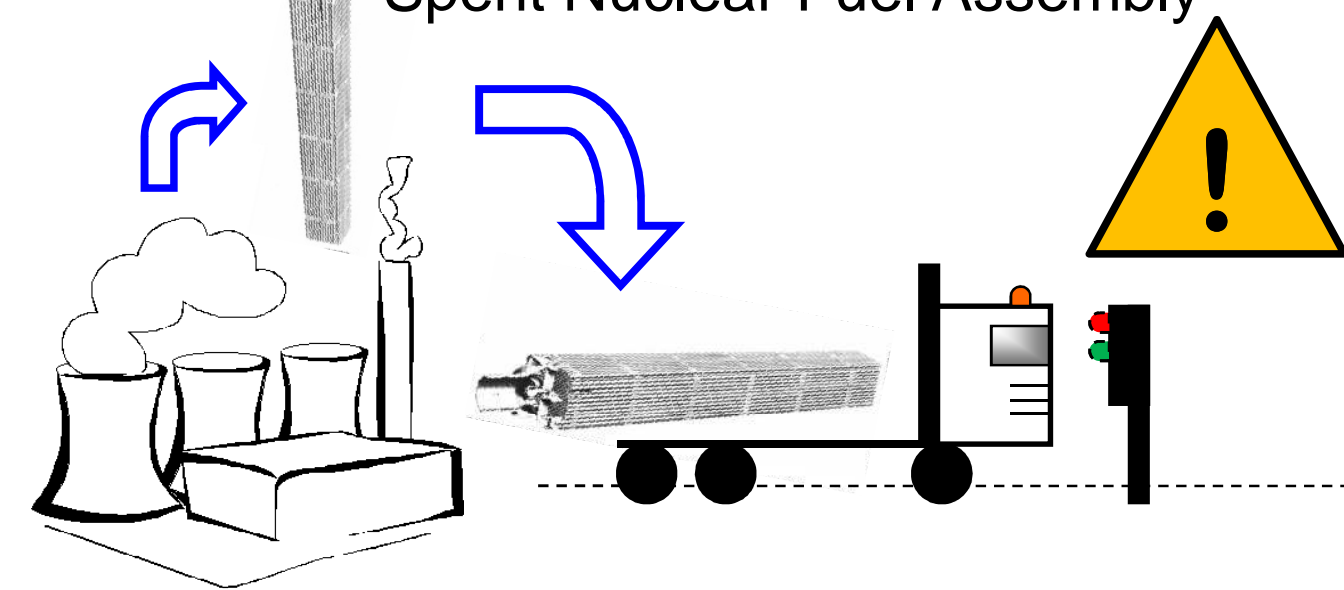

Temperature from $400^{\circ} \mathrm{C}$ up to $450^{\circ} \mathrm{C}$

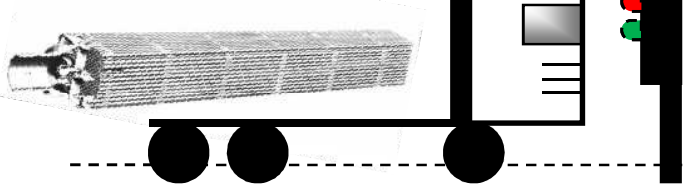

In-reactor use

Fuel assembly

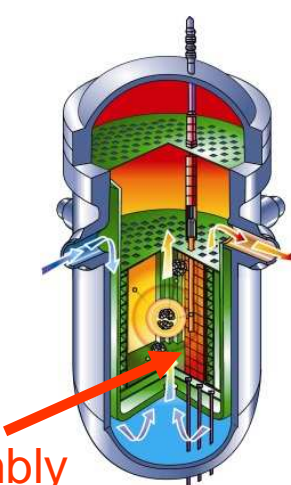

Neutron irradiation of the Zr alloy cladding

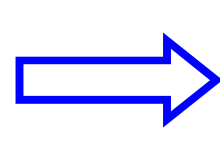

Post-irradiation creep of the Zr alloy cladding and radiation damage recovery

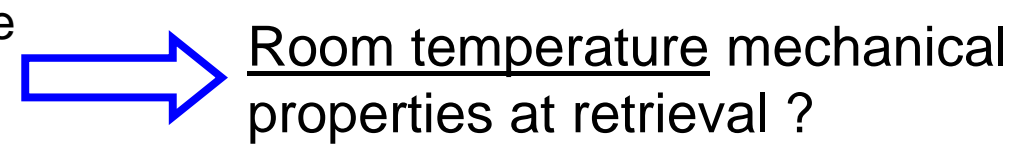




\section{Cea MATERIAL STUDIED AND RADIATION EFFECTS}

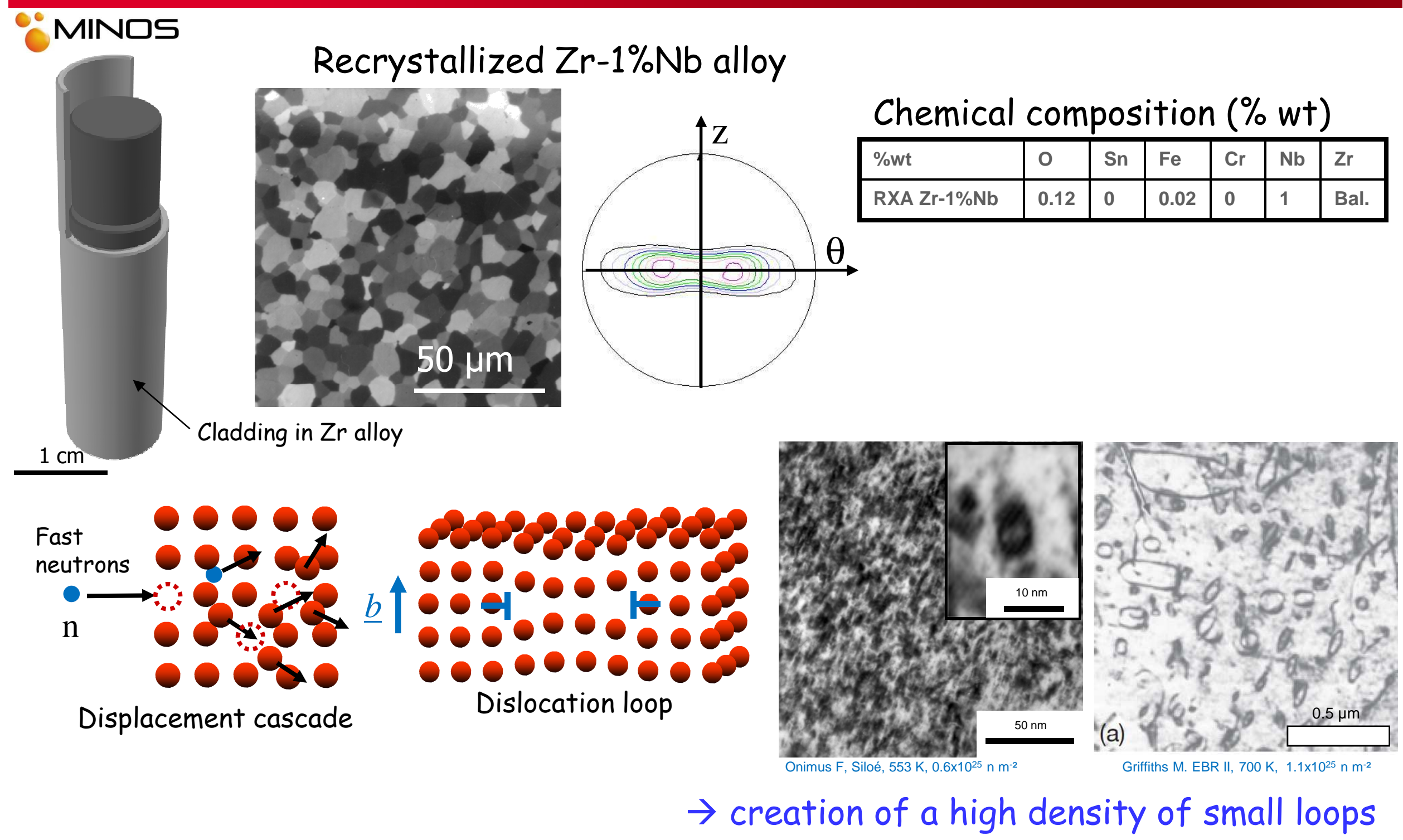




\section{Cea LOOP EVOLUTION DURING HEAT TREATMENT}

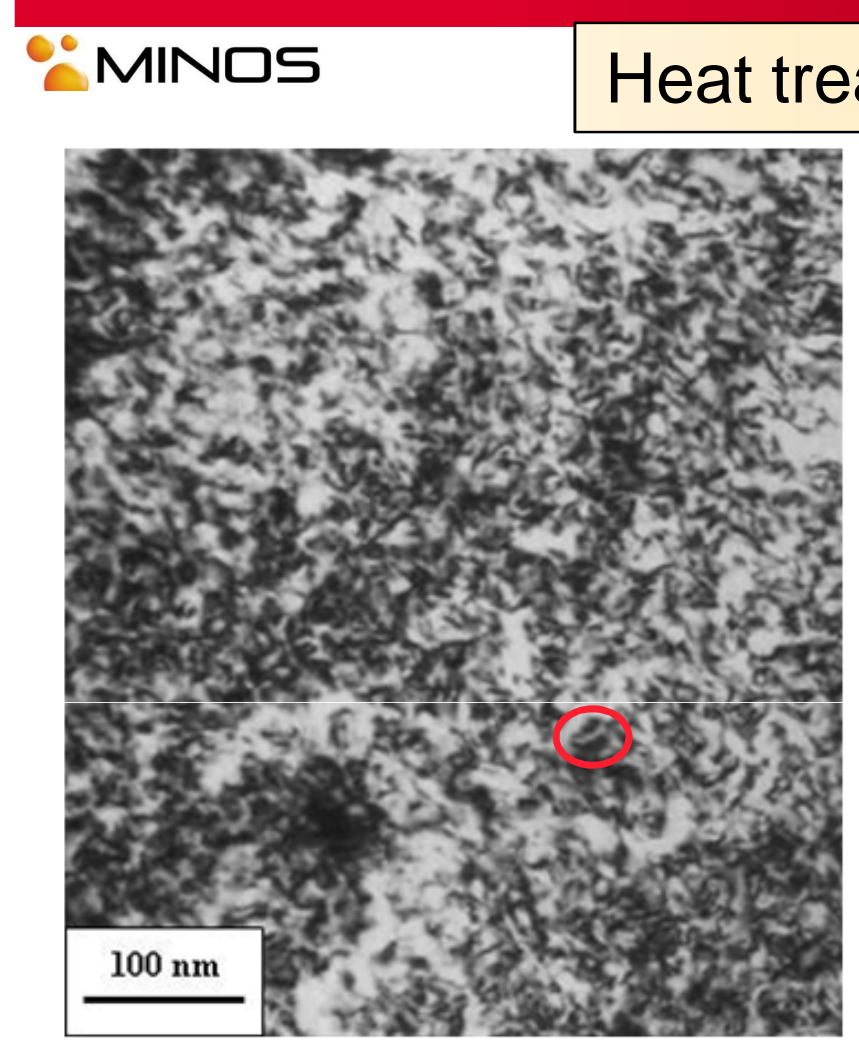

(a)

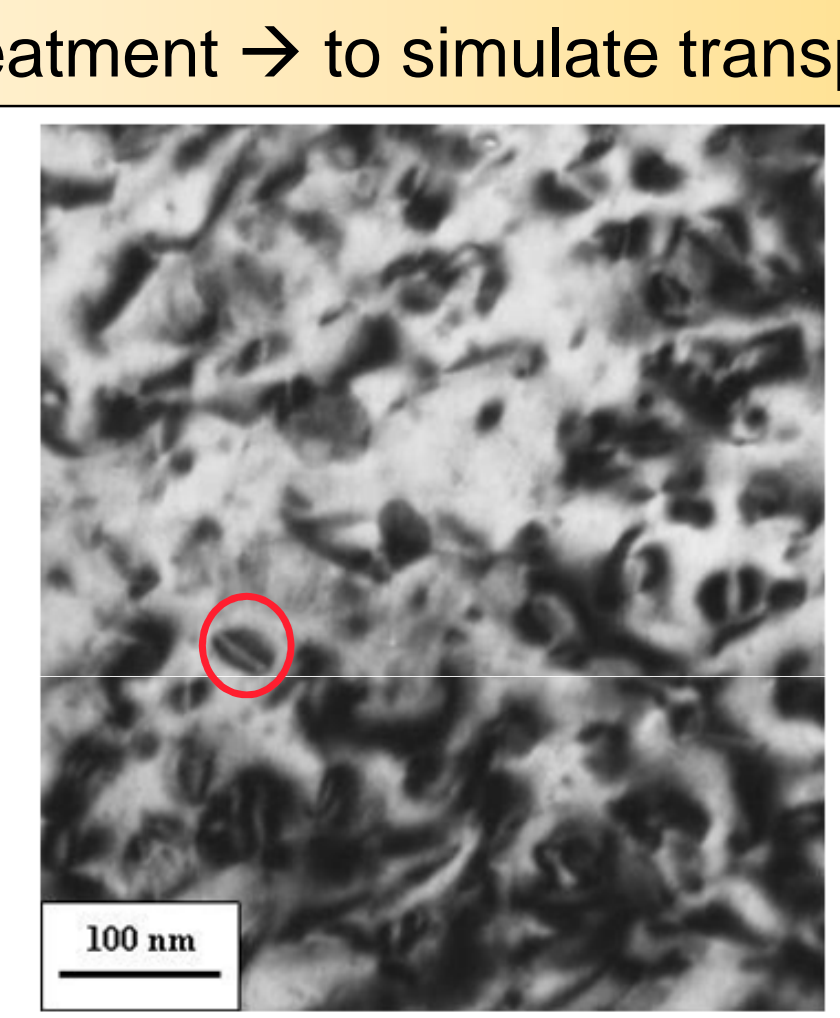

(d)

As-irradiated material

$$
<\rho_{b}>=1,2 \cdot 10^{22} \mathrm{~m}^{-3}
$$

$<\mathrm{d}>=14 \mathrm{~nm}$

\section{portation}

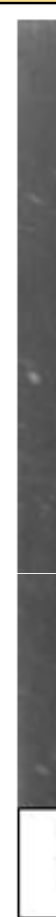

$100 \mathrm{~nm}$

$\underline{-100 \mathrm{nn}}$

(f)

After heat treatment at $450^{\circ} \mathrm{C}$ during $960 \mathrm{~h}$

$$
\begin{aligned}
& <\rho_{b}>=1,2 \cdot 10^{20} \mathrm{~m}^{-3} \\
& <\mathrm{d}>=176 \mathrm{~nm}
\end{aligned}
$$

$\rightarrow$ The loop size increases while the density decreases

$\mathrm{Cr} \rightarrow$ Radiation damage recovery 


\section{Cea LOOP EVOLUTION DURING HEAT TREATMENT}

¿MINDS

Loop nature using inside / outside contrast method

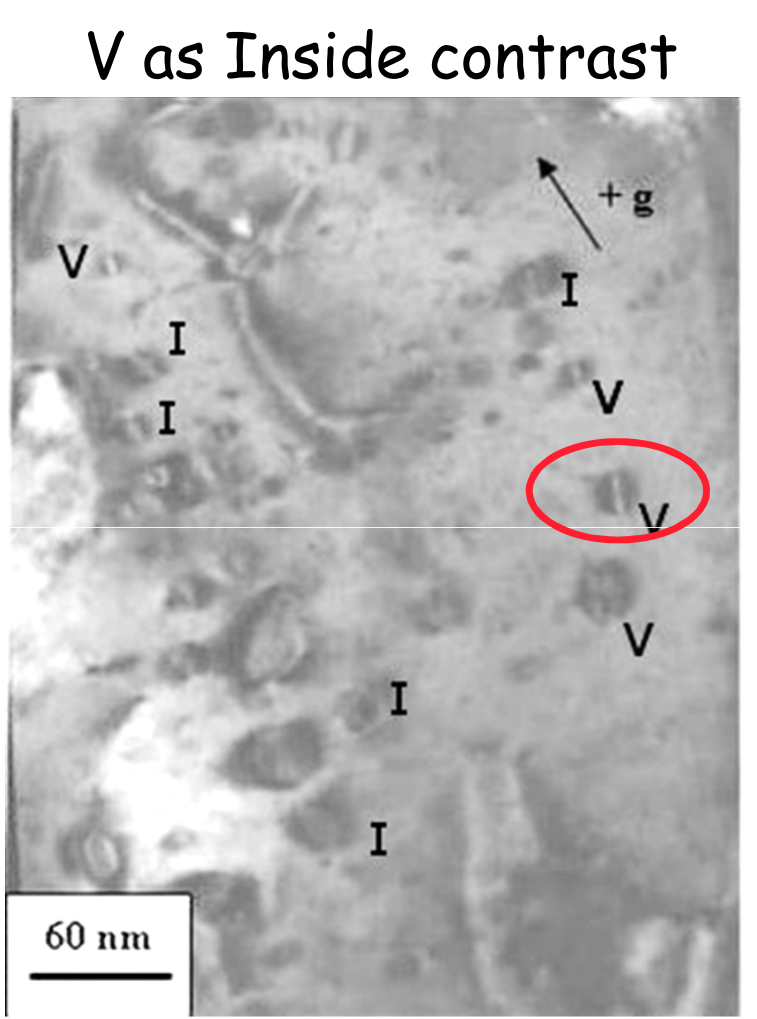

(a)

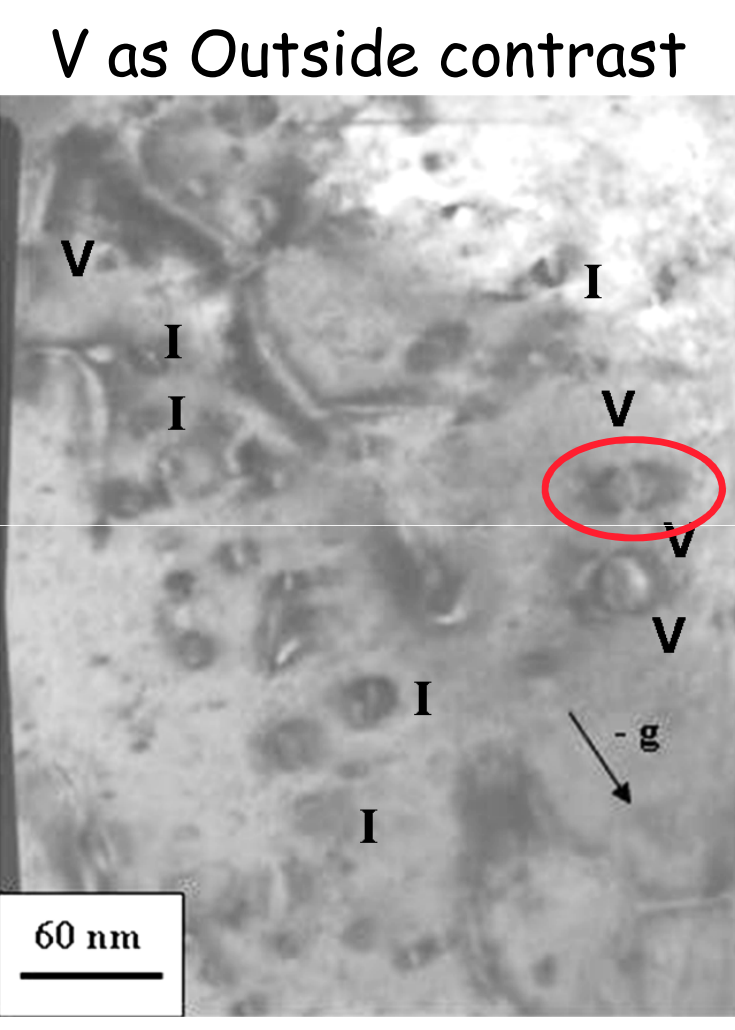

(b)

\begin{tabular}{|l|l|}
\hline Annealing & $\begin{array}{l}\text { Vacancy } \\
\text { loops }\end{array}$ \\
\hline As-irradiated & $50 \%$ \\
\hline $\begin{array}{l}350^{\circ} \mathrm{C} \\
250 \mathrm{~h}\end{array}$ & $50 \%$ \\
\hline $350^{\circ} \mathrm{C}$ \\
$500 \mathrm{~h}$ & $50 \%$ \\
\hline $400^{\circ} \mathrm{C}$ & \\
$250 \mathrm{~h}$ & $65 \%$ \\
\hline $400{ }^{\circ} \mathrm{C}$ & $71 \%$ \\
$500 \mathrm{~h}$ & \\
\hline $450^{\circ} \mathrm{C}$ & $100 \%$ \\
$960 \mathrm{~h}$ & \\
\hline
\end{tabular}

$\rightarrow$ Only vacancy loops at the end of the recovery

$\rightarrow$ Interstitial loops recover faster than vacancy loops

What is the loop recovery mechanism? 


\section{Cea LOOP RECOVERY : MECHANISM}

MIN口S
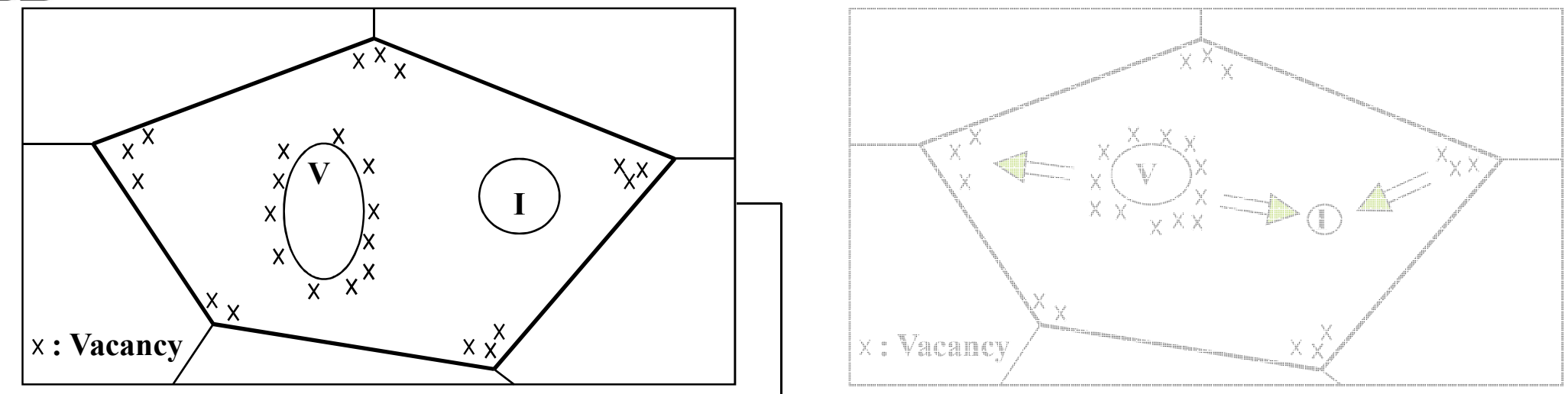

\section{As-irradiated microstructure}
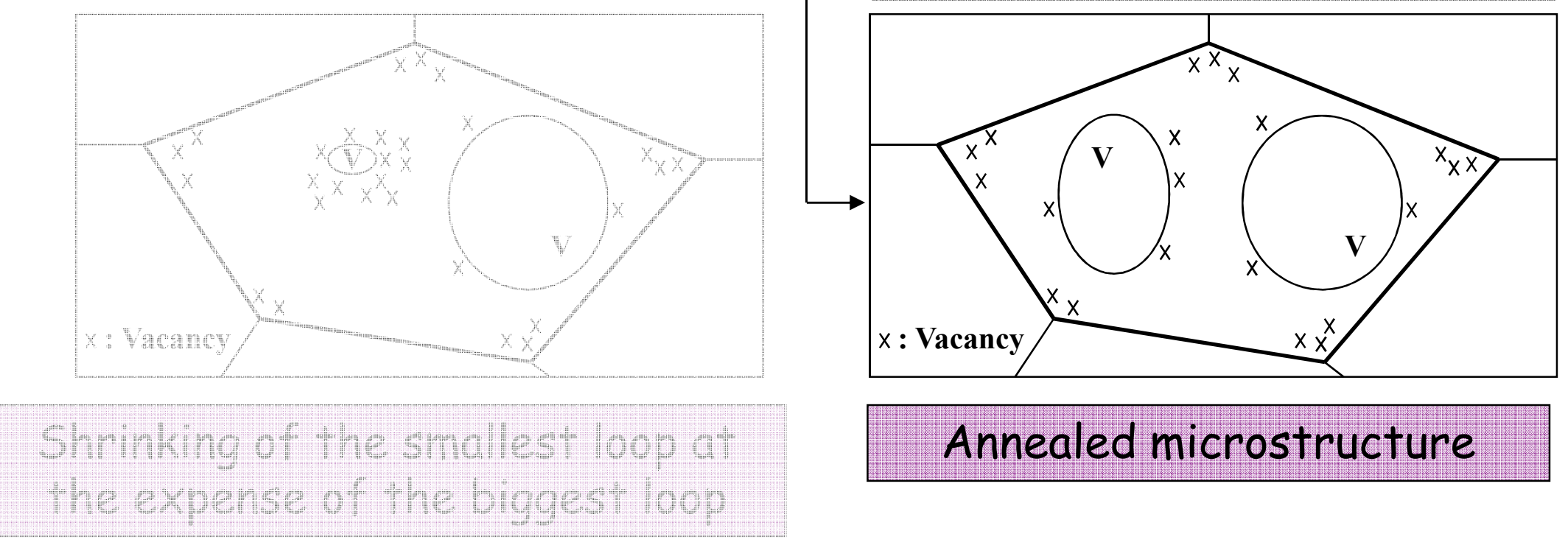

\section{Annealed microstructure}




\section{cea LOOP RECOVERY : MODELLING}

\section{MINDS}

\section{Predictive modelling approach : cluster dynamic}

Single-vacancy evolution :

$$
\begin{aligned}
& \frac{d C_{v}(1)}{d t}=\text { prodluction - annihilation } \\
& \text { No creation of point } \\
& \text { defects during annealing }
\end{aligned}
$$

Cluster evolution :

$\frac{d C(n)}{d t}=a_{n-1} C(n+1)-b_{n} C(n)+c_{n-1} C(n-1)$

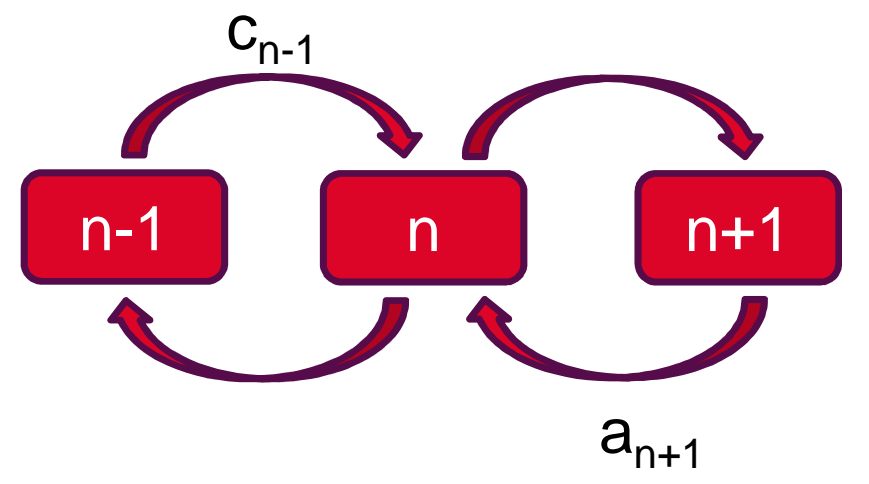

CEA - DEN
Sinks: clusters, dislocation lines, grain boundaries / free surfaces

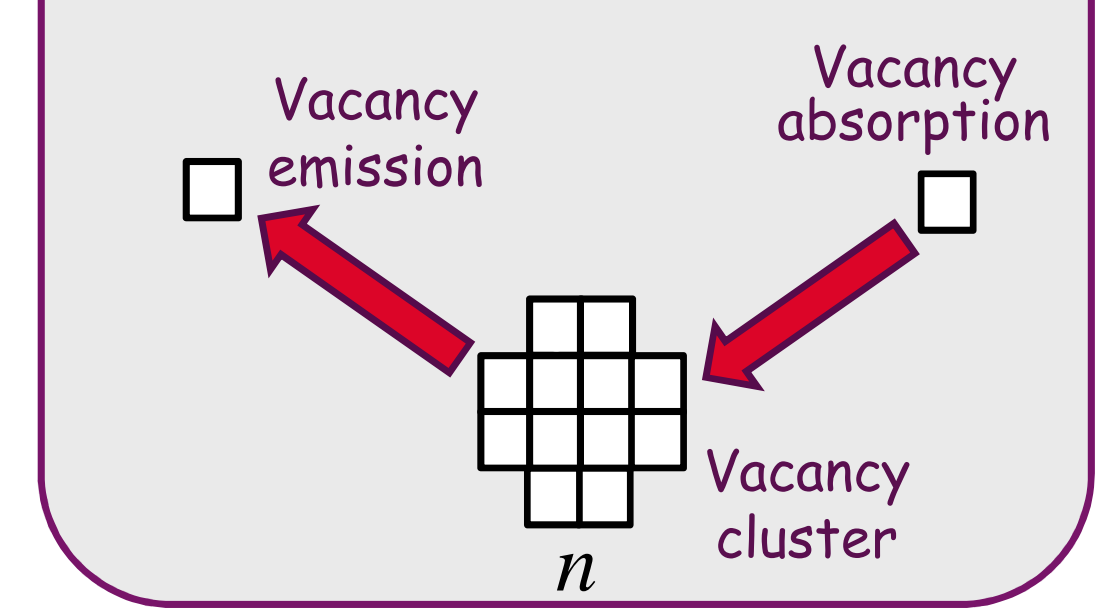




\section{LOOP RECOVERY : MODELLING}

MINDS

Cluster dynamic modelling $\rightarrow$ computation of loop size and density
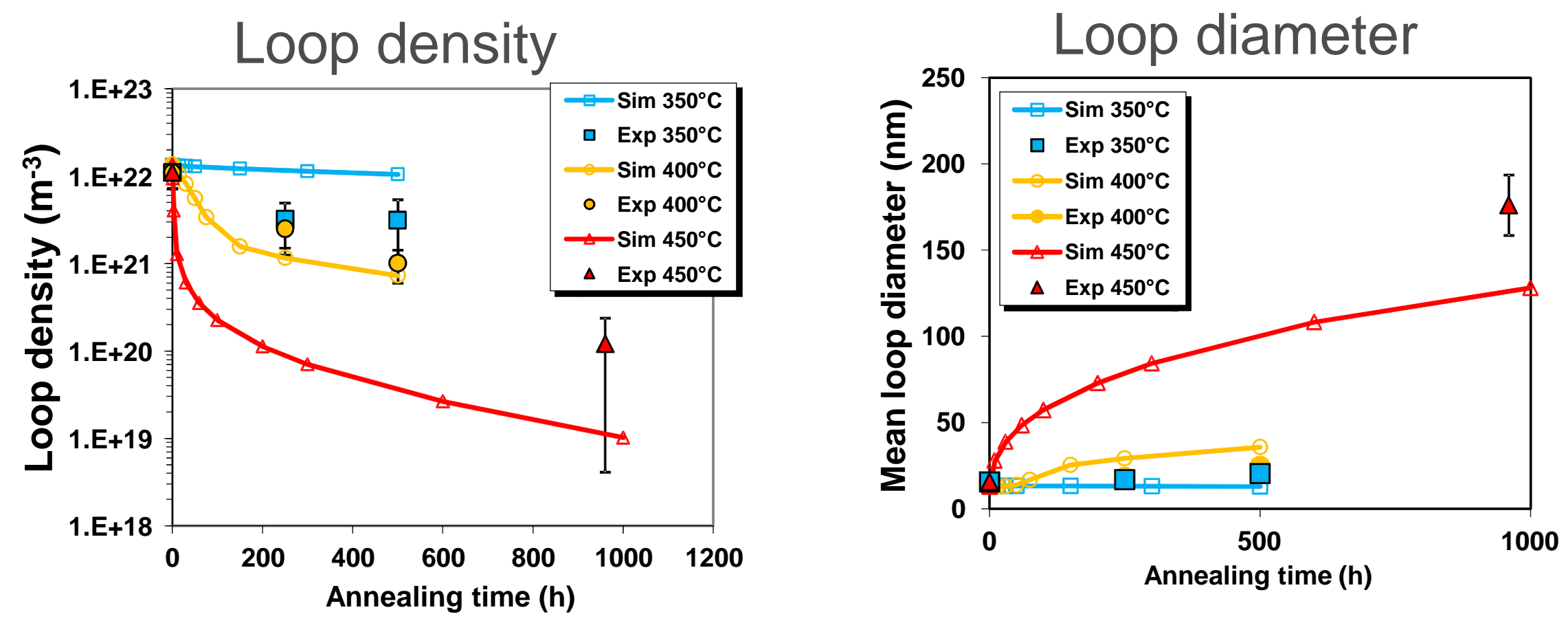

$\rightarrow$ Correct agreement between experiment and modeling 


\section{LOOP RECOVERY : MODELLING}

MINDS Evolution of vacancy and interstitial loop size distribution at $400^{\circ} \mathrm{C}$
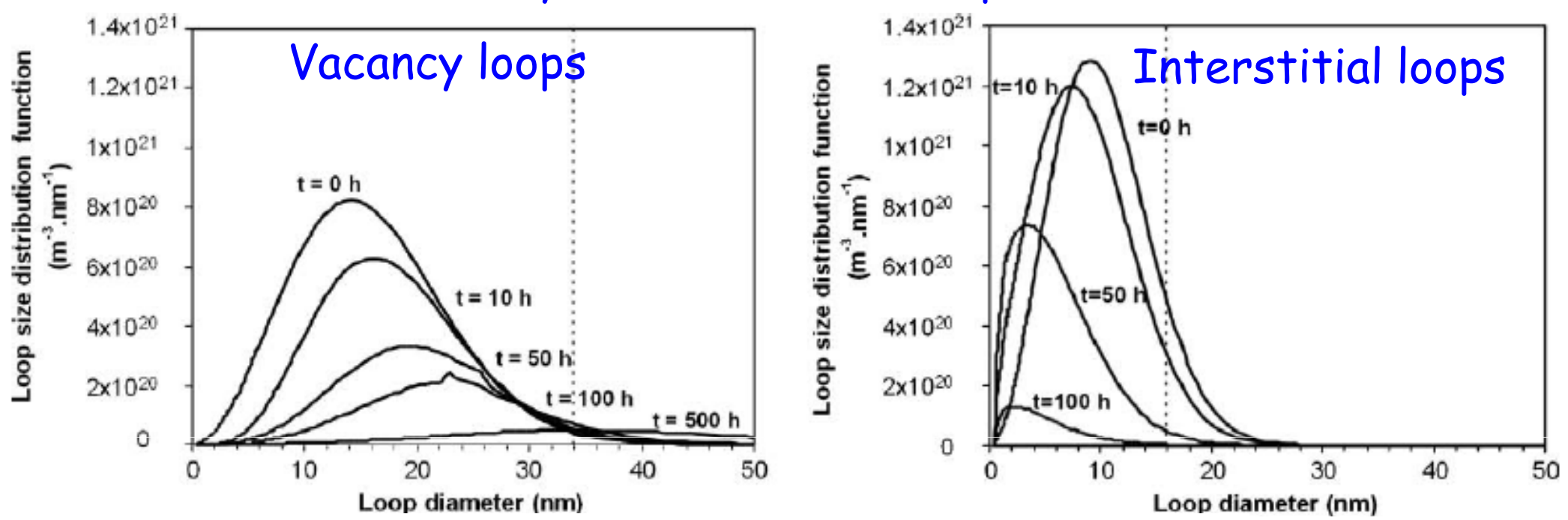

Evolution of the proportion of vacancy loops during heat treatment

\begin{tabular}{|c|c|c|c|c|}
\hline \multirow{2}{*}{$\begin{array}{l}\text { Annealing } \\
\text { temperature } \\
\left({ }^{\circ} \mathrm{C}\right)\end{array}$} & \multirow{2}{*}{$\begin{array}{l}\text { Annealing } \\
\text { time }(\mathrm{h})\end{array}$} & \multicolumn{2}{|l|}{ Experiment } & \multirow{2}{*}{$\begin{array}{l}\text { Modelling } \\
\text { Percentage of } \\
\text { vacancy loops } \\
\text { (\%) }\end{array}$} \\
\hline & & $\begin{array}{l}\text { Number of } \\
\text { analysed } \\
\text { loops }\end{array}$ & $\begin{array}{l}\text { Percentage of } \\
\text { vacancy loops } \\
\text { (\%) }\end{array}$ & \\
\hline As-irradiated & $\begin{array}{l}\text { As- } \\
\text { irradiated }\end{array}$ & - & $50[23]$ & 50 \\
\hline 350 & 250 & 19 & 50 & 45 \\
\hline 350 & 500 & 24 & 50 & 43 \\
\hline 400 & 250 & 37 & 65 & 100 \\
\hline 400 & 500 & 38 & 71 & 100 \\
\hline 450 & 960 & 13 & 100 & 100 \\
\hline
\end{tabular}

$\rightarrow$ Correct agreement between experiment and modeling 


\section{Cea RADIATION HARDENING RECOVERY : MODELING}

\section{MIN口S}

High density of small loops

$\rightarrow$ pinning of dislocations

$\rightarrow$ radiation hardening
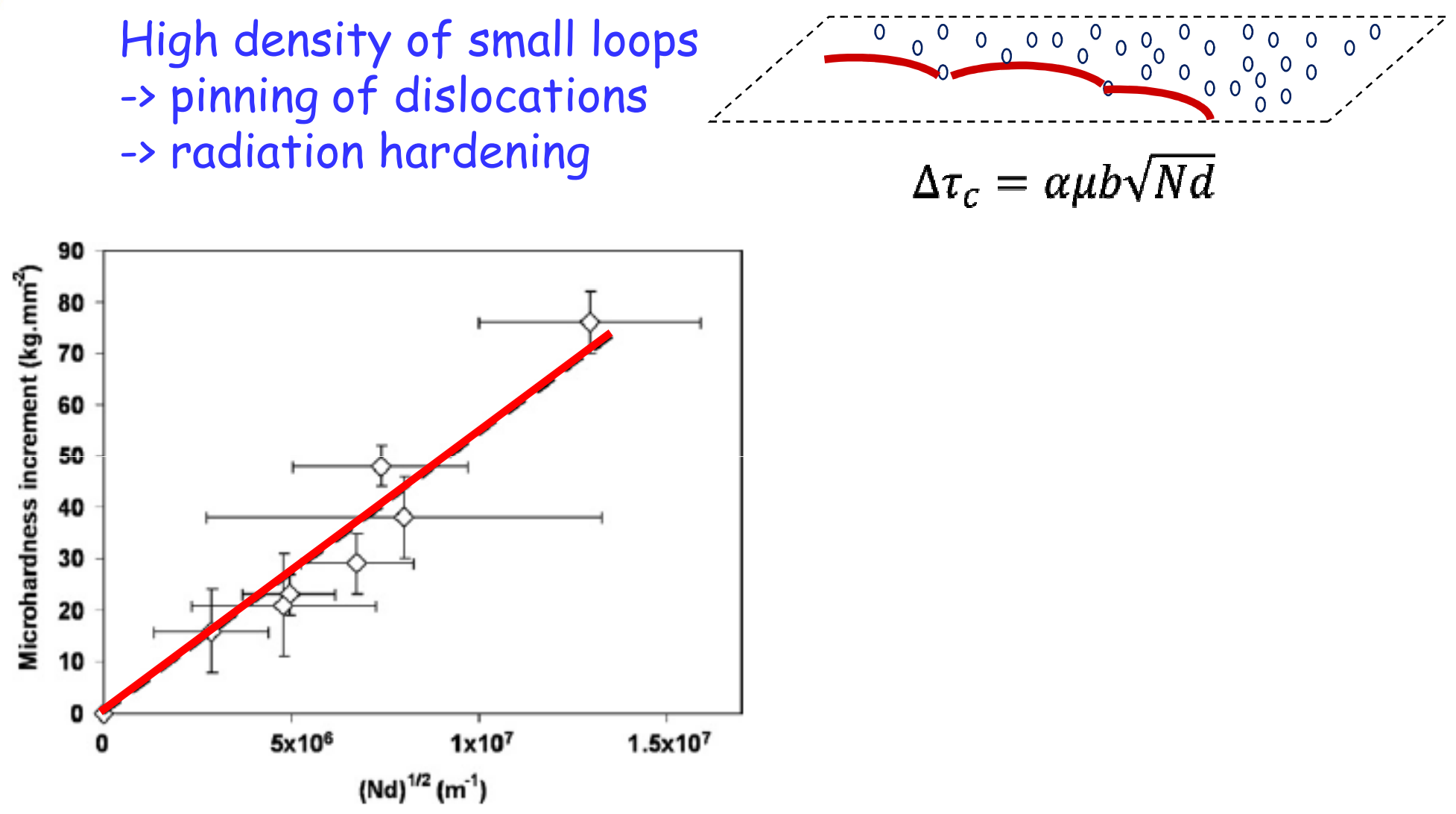

Hardness as a function of the loop density \& size

$\rightarrow$ Radiation hardening recovery during heat treatment $\rightarrow$ Correct prediction of radiation hardening recovery 


\section{CeZ LOOP RECOVERY DURING POST-IRRADIATION CREEP}
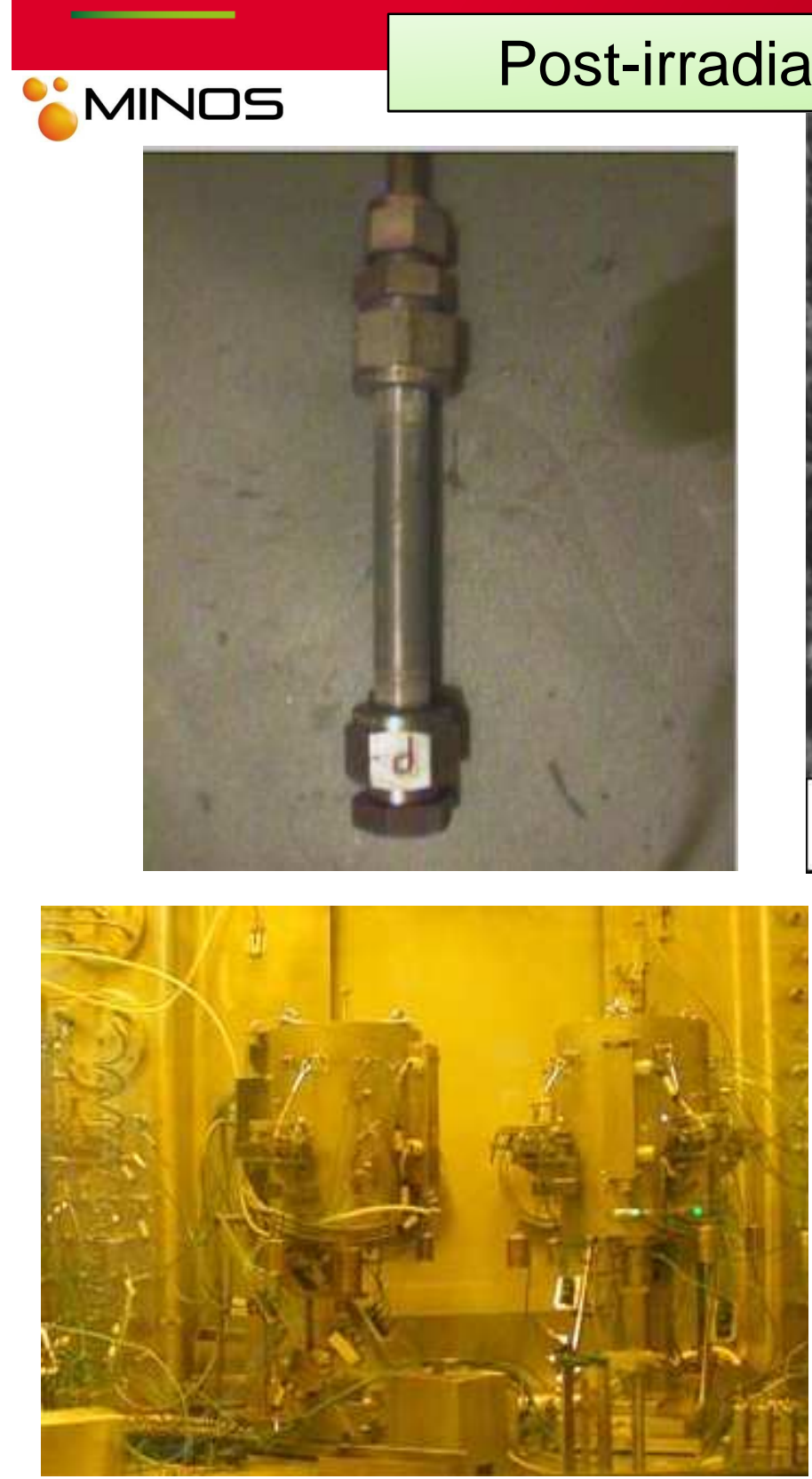

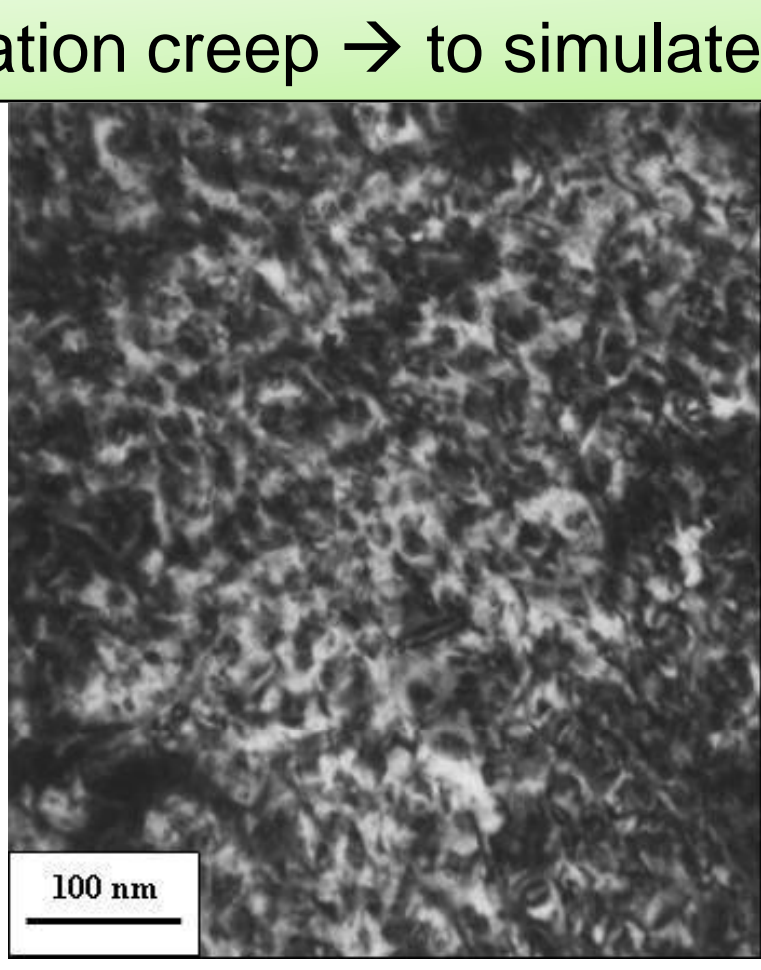

As-irradiated

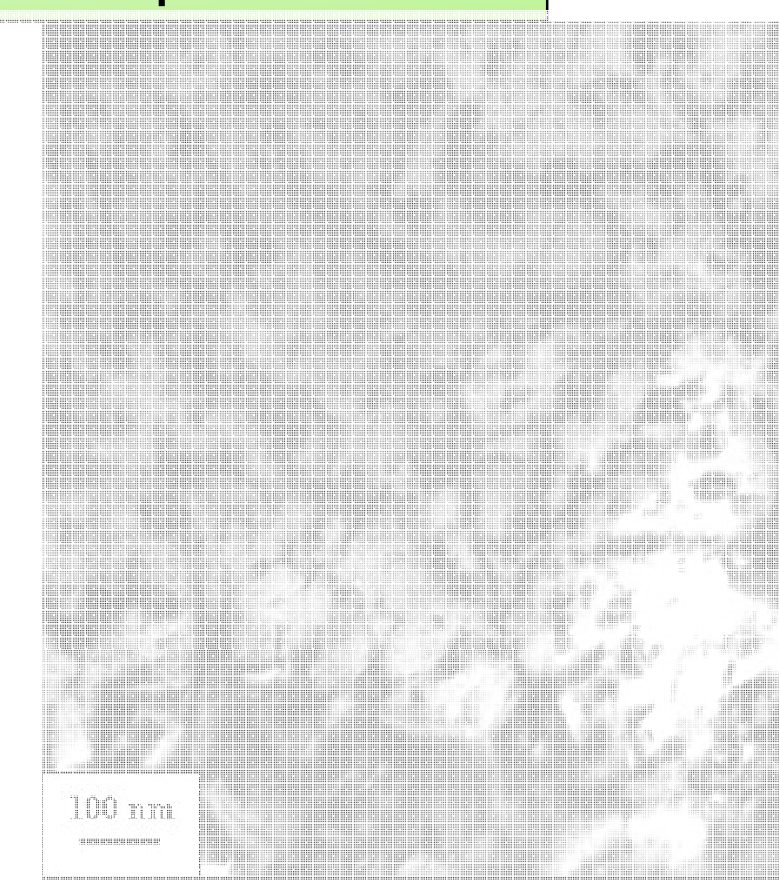

Creep test at $400^{\circ} \mathrm{C}$ during 240 h unden $130 \mathrm{MPa}$

After post-irradiation creep :

$\rightarrow$ decrease of the loop density

( + increase of the loop size)

$\rightarrow$ Radiation damage recovery during creep

$\rightarrow$ Effect on the tensile mechanical behavior? 


\section{Cea IMPACT ON ROOM TEMPERATURE BEHAVIOR}

\section{MIN口S}

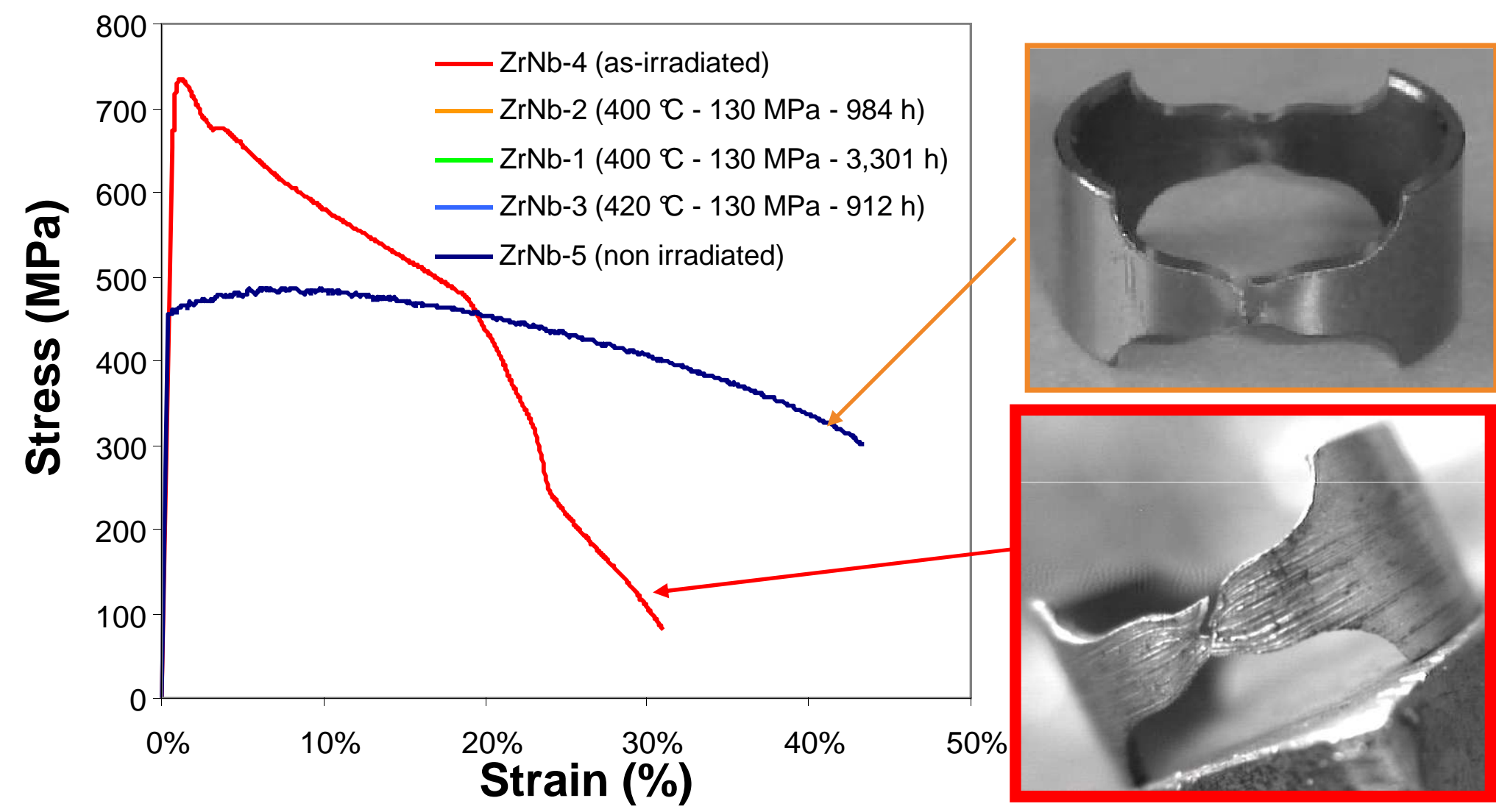

- Irradiation induced hardening (increase of the yield stress and ultimate tensile strength)

- Loss of macroscopic ductility (decrease of the uniform elongation), but the failure remains ductile (strong necking)

$\rightarrow$ What are the deformation mechanisms? 


\section{CEZ DEFORMATION MECHANISM OF AS-IRRADIATED MATERIAL}

\section{MINDS}

RT tensile test on non irradiated material
Ring tensile test at room temperature after irradiation

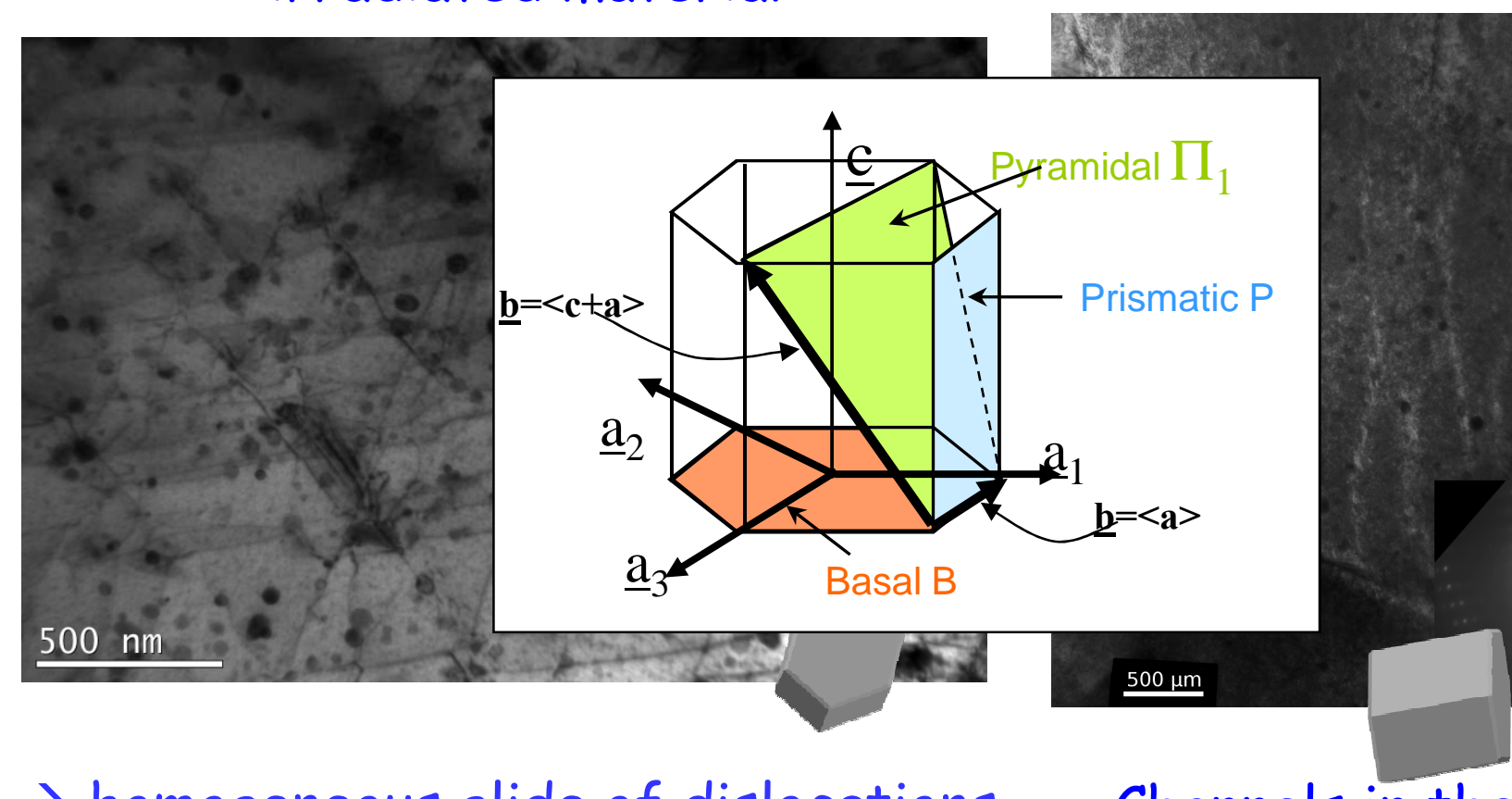

Channels in the basal plane

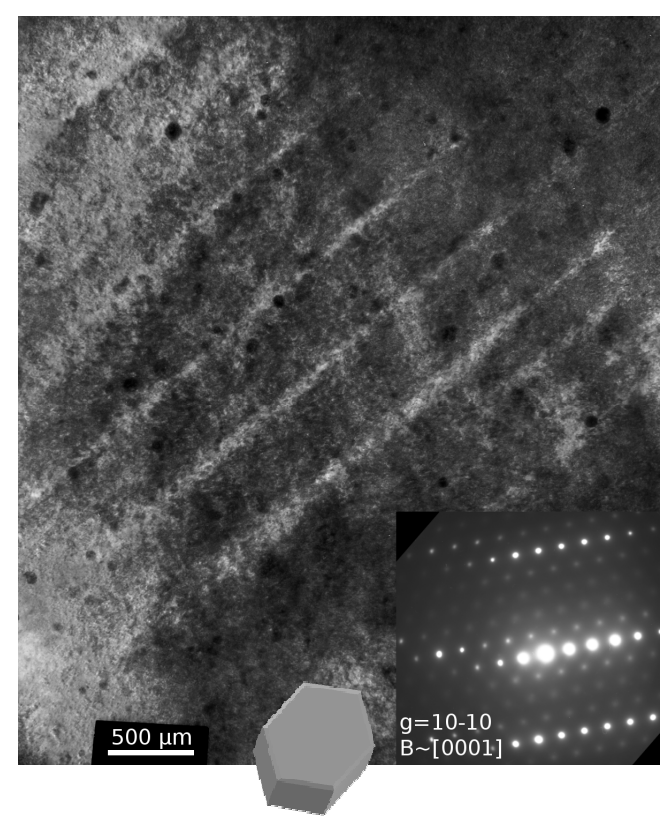

Channels in the prismatic planes in the prismatic planes mainly

- Heterogeneous deformation inside the grains (dislocation channeling)

- both basal and prismatic slip can be activated (depending on the grain orientation)

$\rightarrow$ easier basal slip than before irradiation 


\section{Cea DEFORMATION MECHANISM OF AS-IRRADIATED MATERIAL}

$0^{0} \cdot \cdots \cdot-$

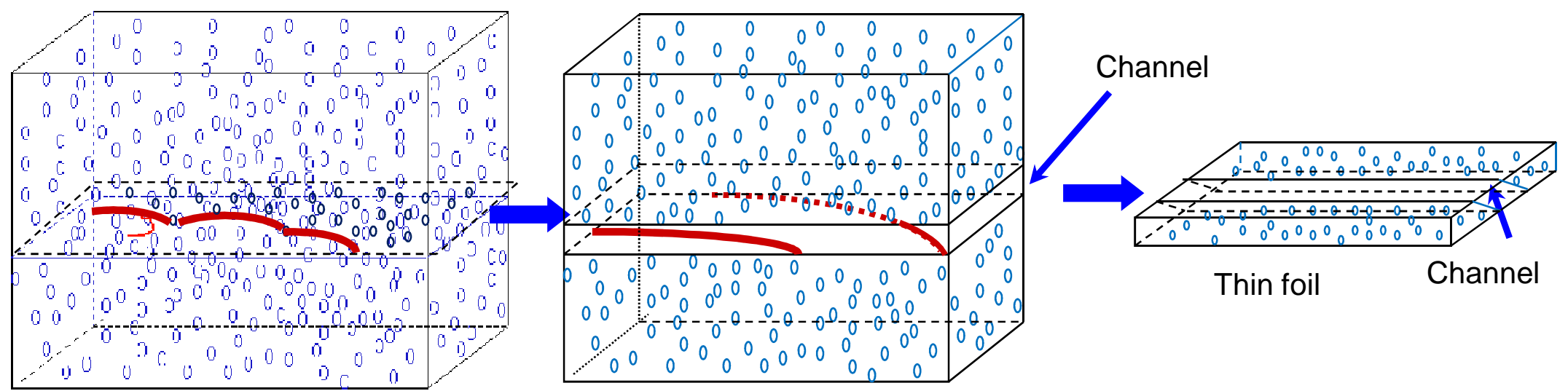

High density of small loops

$\rightarrow$ pinning of dislocations

$\rightarrow$ radiation hardening

Clearing of loops by gliding dislocations

$\rightarrow$ microscopic strain softening

$\rightarrow$ early localization of the deformation at the specimen scale

$\rightarrow$ decrease of the Uniform Elongation observed during ring tensile tests

$\rightarrow$ Why is the basal slip more easily activated after irradiation than before irradiation? 


\section{CEZDEFORMATION MECHANISM OF AS-IRRADIATED MATERIAL}

MIN口S

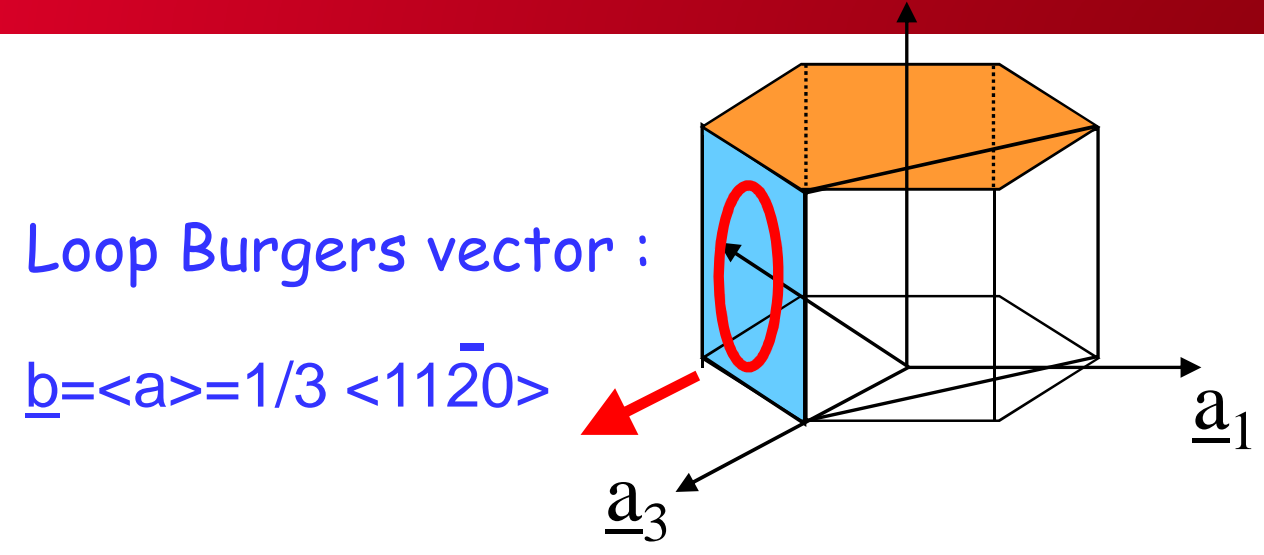

Dislocation Burgers vector : $\underline{b}=<a>=1 / 3<11 \overline{20}\rangle$
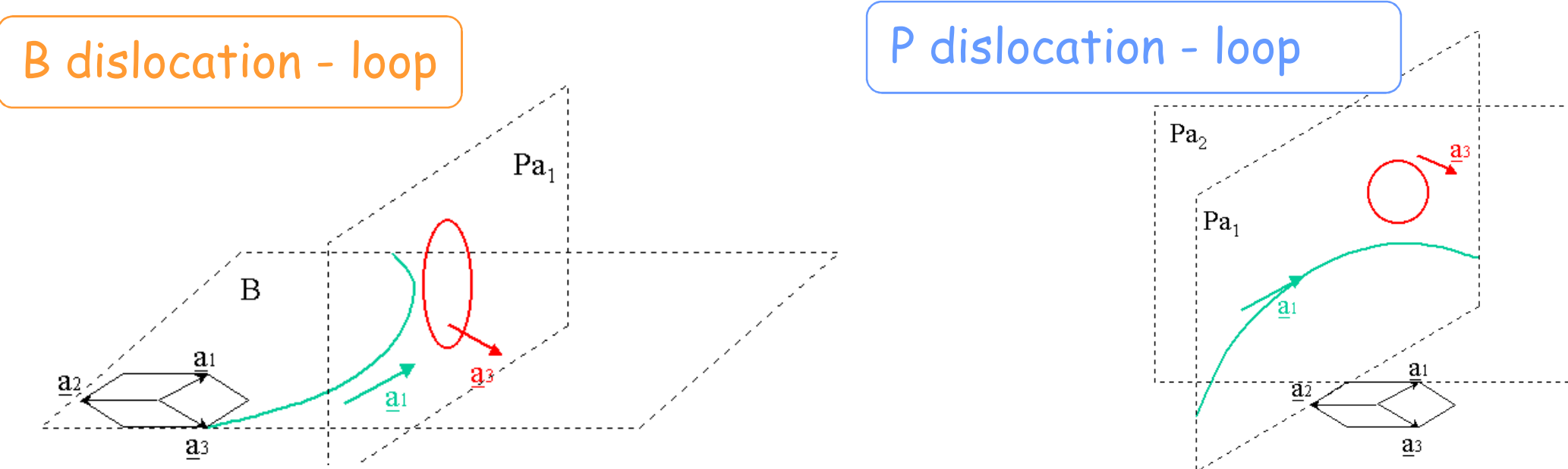

$\longrightarrow$ Glissile junction

$\rightleftarrows$ Sessile junction

$\rightarrow$ Easy Basal channeling / difficult Prismatic channeling 


\section{Cea IMPACT ON ROOM TEMPERATURE BEHAVIOR}

MIN口S
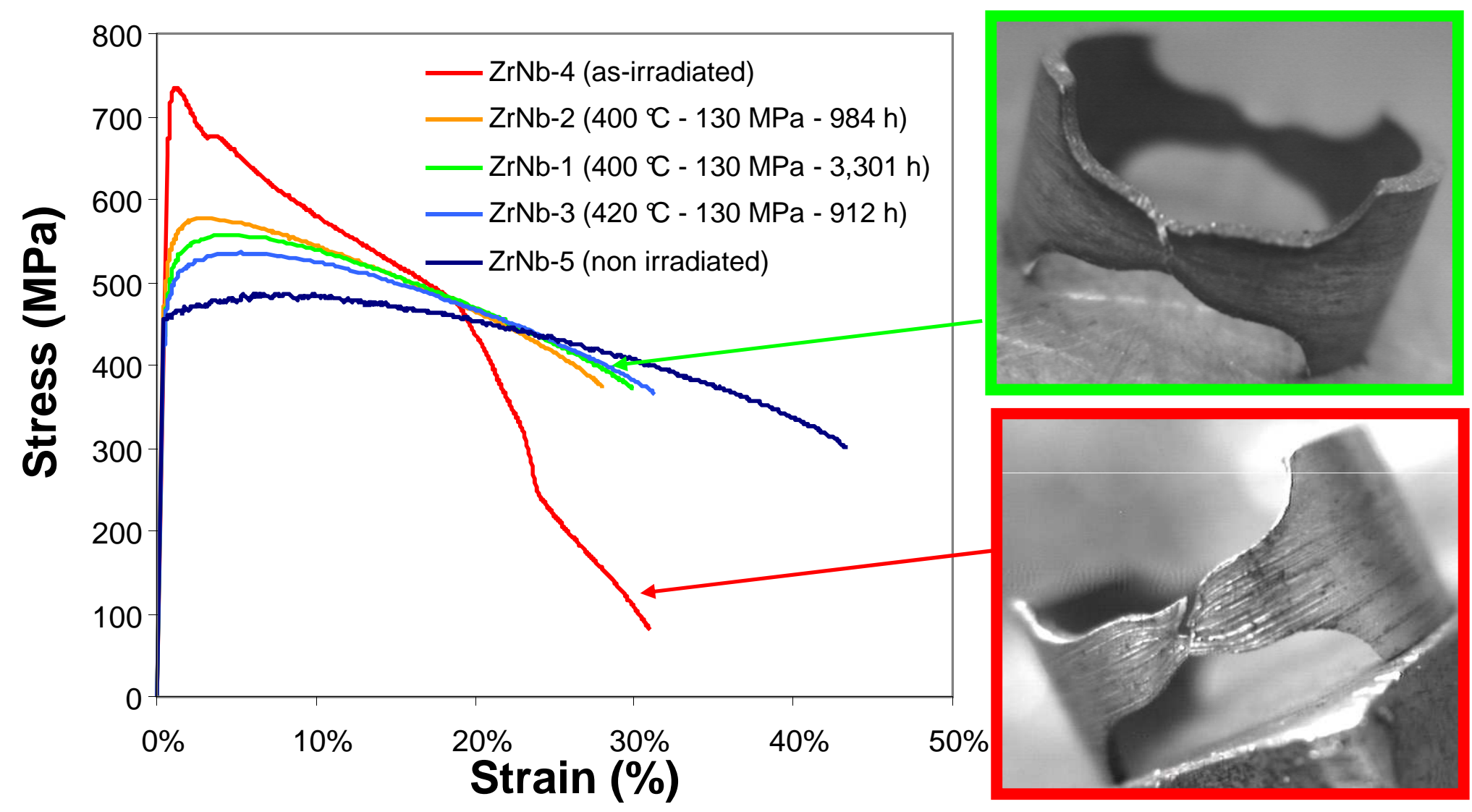

- Recovery of the radiation induced hardening after creep test

- Recovery of the macroscopic ductility (uniform elongation)

$\rightarrow$ What are the deformation mechanisms? 


\section{Cea IMPACT ON ROOM TEMPERATURE BEHAVIOR}

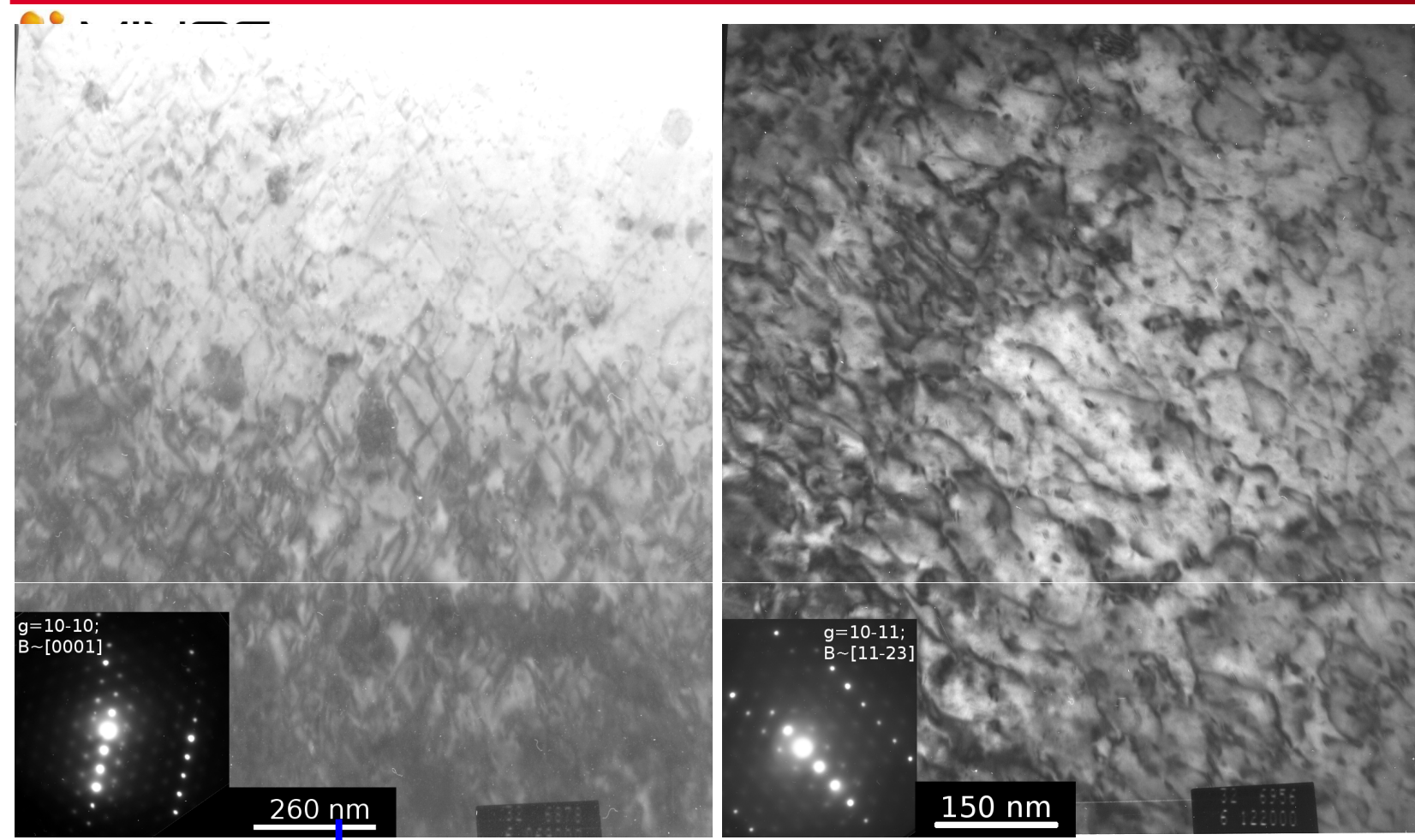

Testing after creep at $400^{\circ} \mathrm{C}$

Prismatic glide mainly

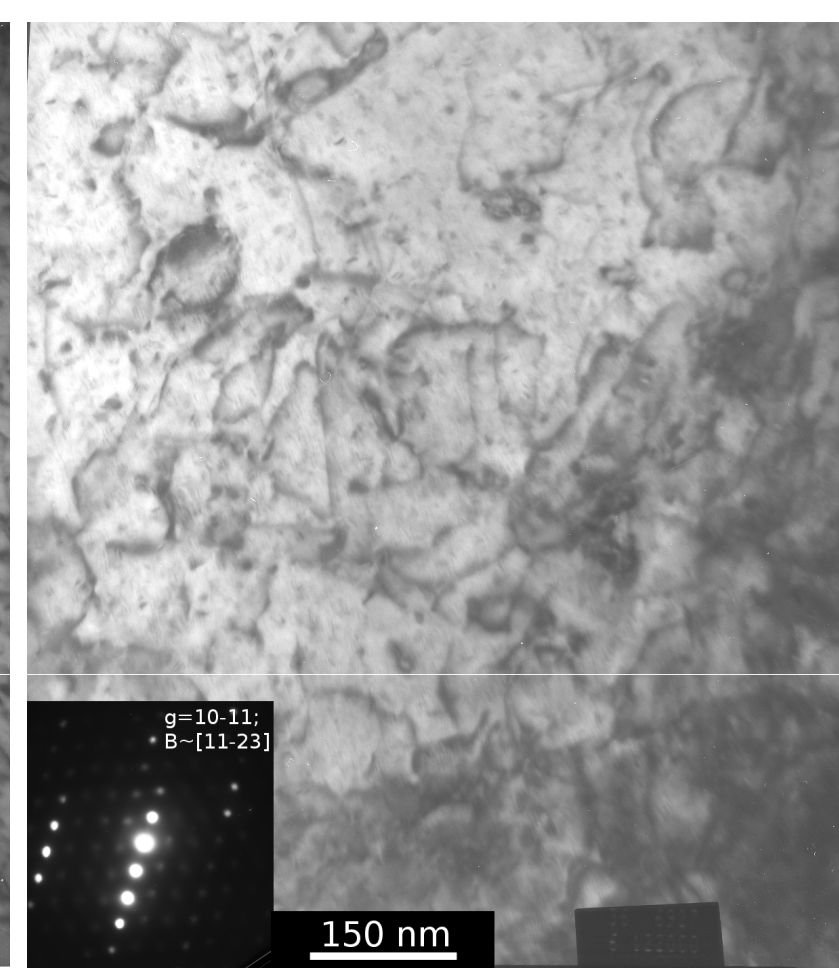

Testing after creep at $420^{\circ} \mathrm{C}$

After ring tensile test following post-irradiation creep :

$\rightarrow$ very few remaining loops $\rightarrow$ lower radiation hardening

$\rightarrow$ homogeneous prismatic glide mainly, no channel

$\rightarrow$ recovery of the uniform elongation 


\section{cea CONCLUSIONS}

Radiation damage recovery:

- Occurs by exchange of vacancies between loops

$\rightarrow$ Shrinking of Int loops and of small Vac loops at the expense to bigger Vac loops

Cluster dynamic modeling:

$\rightarrow$ Correct prediction radiation damage recovery \& radiation hardening recovery

Mechanical behavior after neutron irradiation:

- decrease of the uniform elongation due to the dislocation channeling

- failure occurs after a strong necking $\rightarrow$ ductile failure

- evolution of activated slip systems explained by junction between dislocations and loops

Impact of transportation (post-irradiation creep) :

- radiation hardening recovery due to the loop annealing during creep

- recovery of the uniform elongation due to homogeneous glide of dislocations

$\rightarrow$ better knowledge and understanding of the effects of transportation on the mechanical properties of the fuel assembly at retrieval 


\section{cea}

\section{MINOS}

\section{Thank you!}

